\title{
THE VEGETATION AND FLORA OF THE COAL RIVER NATURE RESERVE
}

\author{
by K.A. Johnson and J.B. Kirkpatrick
}

(with four tables, four text-figures and an appendix)

Johnson, K.A. \& Kirkpatrick, J.B., 1996 (30:vi): The vegetation and flora of the Coal River Nature Reserve. Pap. Proc. R. Soc. Tasm. 130(1): 15-23. hrtps://doi.org/10.26749/rstpp.130.1.15 ISSN 0080-4703. Department of Geography and Environmental Studies, University of Tasmania, Box 252C, GPO, Hobart, Australia 7001.

The Coal River Gorge Nature Reserve occupies most of a sandstone gorge and some adjacent hilltops in a dry part of Tasmania, the vegetation of which is poorly documented. Three dry sclerophyll and two wet sclerophyll plant communities were selected from a TWINSPAN analysis of higher plant species presence-absence data from 200 quadrats. The plant communities formed a continuum from heathy Eucalyptus tenuiramis, heathy E. amygdalina and grassy/shrubby E. obliqua dry sclerophyll communities to E. obliqua-Pomaderris and E. obliqua-Olearia wet sclerophyll communities. This continuum was related to the catena from the cliff top environments (altitude $350 \ldots 450 \mathrm{~m}$ ) to the base of the gorge (approximately $200 \mathrm{~m}$ ). Soil moisture appeared to be a major variable related to the change in floristics and structure of the vegetation. The reserve, being small and downslope of developed land, has management problems related to nutrient drift, stock grazing and fire.

Key Words: flora, vegetation, dry sclerophyll forest, environmental relationships, conservation, Coal River Gorge, Tasmania.

\section{INTRODUCTION}

The characteristics and ecology of the main vegetation types in Tasmania have been well documented (e.g. Jackson 1968 , Kirkpatrick 1977, Brown \& Podger 1982, Ellis 1985, Kirkpatrick 1991). Studies on plant ecology of particular areas in Tasmania have tended to be concentrated in the west of the state and on the east coast. There are relatively few vegetation descriptions of areas within the dry southeastern-central region of thestate (Hogg \& Kirkpatrick 1974, Brown \& Bayly-Stark 1979, Duncan \& Harris 1983). The Coal River Gorge Nature Reserve is situated in the centre of this region. It incorporates a large part of the sandstone gorge of the Coal River $3 \mathrm{~km}$ northeast of Colebrook (fig. 1). It is one of the few secure reserves in this part of Tasmania. The documentation of the flora and plant communities of the reserve system is important in determining both gaps in its coverage and appropriate management.

In this paper we document the flora and vegetation of the Coal River Gorge Nature Reserve, analyse relationships between floristically defined communities and environmental conditions, and assess the conservation significance of our results.

\section{THE STUDY AREA}

An area of approximately 209 ha on the Coal River was proclaimed a State Reserve in December 1980, under the National Parks and Wildlife Act. Prior to reservation, the area was comprised of freehold land on the western side of the river and crown land, on which grazing leases were held, on the eastern side. From 1978 to 1980 the Lands Department acquired blocks or parts of blocks of this freehold land and terminated grazing leases on crown land which formed integral parts of the gorge. The freehold land acquired by the Lands Department was considered unlikely to be used for agricultural purposes.

The Reserve is located predominantly on sandstones and siltstones of lower Triassic age, except where it has cut into Upper Permian carbonaceous mudstones and siltstones at its southern end (Brighton map sheet 8312N, 1975;
Oatlands map sheet 83138,1975$)$. The gorge has been incised to greater than $200 \mathrm{~m}$ along most of its length and is flanked by extremely steep cliffs. The reserve ranges in altitude from approximately $200 \mathrm{~m}$ to $450 \mathrm{~m}$.

The mean annual rainfall at Colebrook is about 630 $\mathrm{mm}$. It is relatively evenly distributed throughout the year (fig. 2). The mean daily temperatures in the Reserve are likely to be slightly lower than those given for Hobart Airport, the closest temperature station (fig. 3).

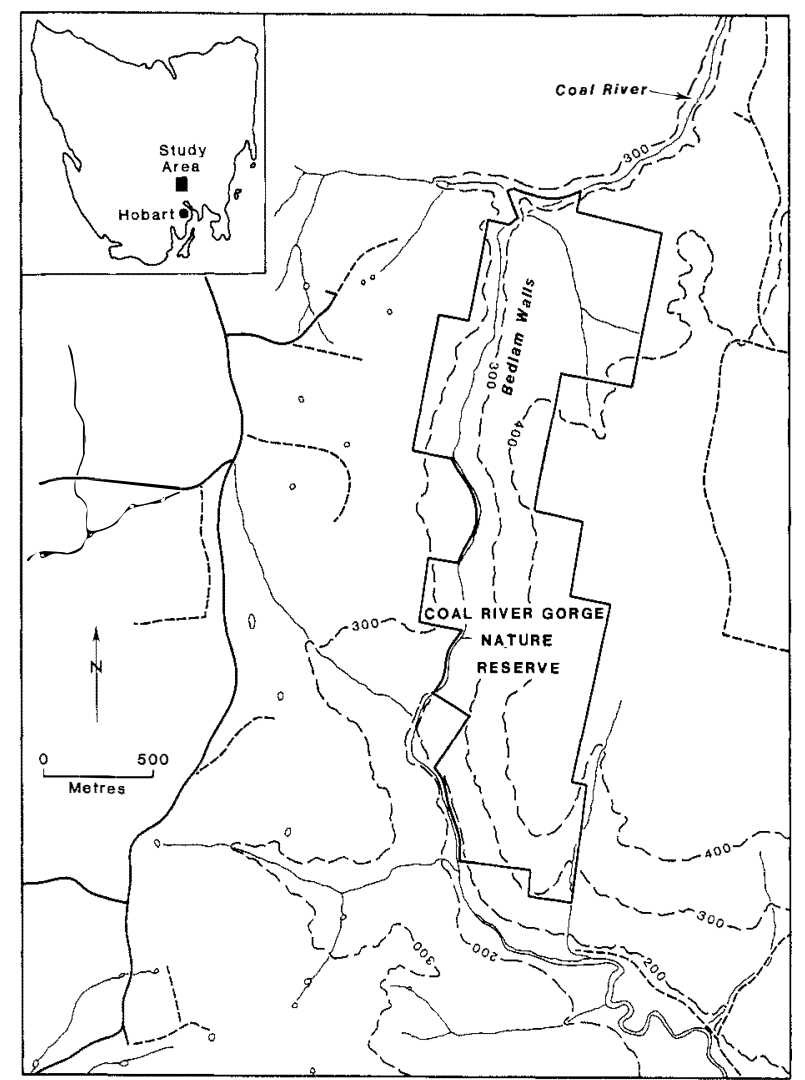

FIG. 1 - Location of the Coal River Gorge Nature Reserve in southeastern Tasmania. 


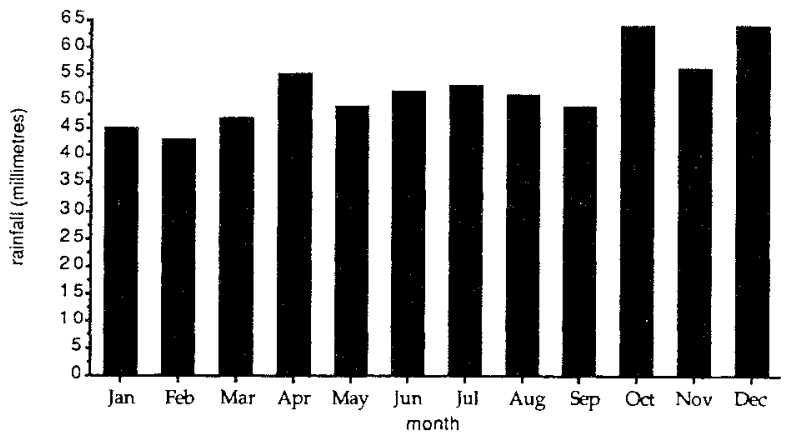

FIG. 2- Mean monthly precipitation at Colebrook between 1974 and 1991. Source: Bureau of Meteorology, Hobart.

\section{METHODS}

One hundred $5 \times 5 \mathrm{~m}$ quadrats were located in a stratified random manner. This size was considered to be sufficient to characterise the floristic composition of the vegetation, when combined with Bitterlich Wedge measurements (Mueller-Dombois \& Ellenberg 1974) for the taller component. The reserve was divided into four environments: cliff top (48 quadrats); eastern slopes (18 quadrats); western slopes (18 quadrats); base of gorge (16 quadrats). A grid was placed over an aerial photograph of the Reserve and a random numbers table (Kmietowicz \& Yannoulis 1976) was used to establish sampling locations. A further 100 quadrats were subjectively located in areas deemed not sufficiently covered by the stratified random location of sites (fig. 4). Most sites were in the reserve, buc 11 sites were located on adjacent private property. Vegetation sampling took place from June to August 1992.

A list of the observed vascular plant species was compiled for each quadrat, and the dominant tree and shrub species were recorded. Species names follow Buchanan (1995). The percentage cover of trees, shrubs, ferns, grasses, leaf licter and rocks, and the amount of bare ground at each site were noted, and the average heights of trees, shrubs and ferns were estimated. The Bitterlich Wedge method was used to gain an estimate of basal area of trees at each quadrat. This method includes all plants with stems at eye height.

Within each quadrat the aspecr (determined by compass), degree of slope (determined by clinometer), drainage and topographical position (cliff top, cliff, alluvial slopes or valley) were recorded. A soil sample was collected at each sice.

The $\mathrm{pH}$ of each soil sample was determined by the use of a CSIRO test kit. Each sample was rested three times, and the average of these readings was taken to be the $\mathrm{pH}$ of the sample. The percentage weight loss on ignition was determined for each soil sample by the method ourlined in Walter (1974). The weight loss on ignition provides an indication of the organic content of the soil.

Communities were selected from a sorted rable of floristic quadrat data produced by the polythetic divisive classificatory programme TWINSPAN (Hill 1979). Mean values and standard deviations were used to describe the following characteristics of the plant communities and their environments: total species richness in quadrats; exotic species richness; endemic species richness; $\mathrm{pH}$; and percentage weight loss on ignition.

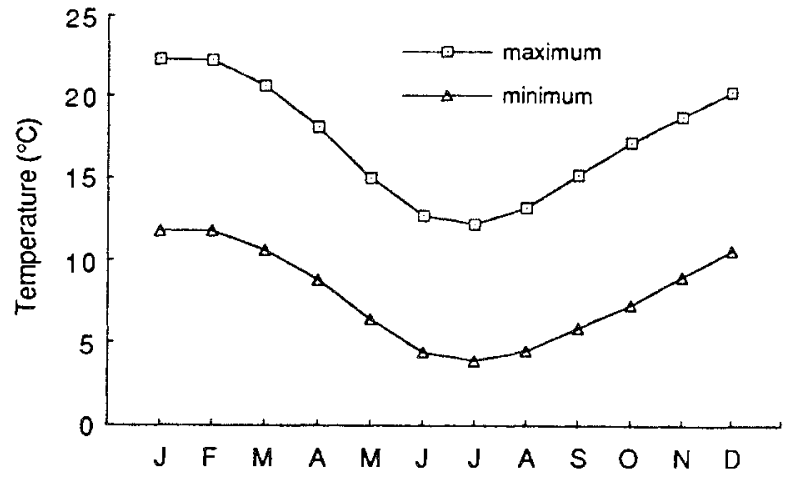

FIG. 3 - Mean daily temperatures from Hobart airport (approximately $50 \mathrm{~km}$ south of the Reserve) between 1944 and 1989. Source: Bureau of Meteorology, Hobart.

Aerial photograph interpretation, field observation and the quadrat data were used to produce a vegetation map that indicates the distribution of floristic communities.

Depending on the characteristics of the data, chi-squared, Students t-test or the Mann-Whitney U test (Siegel 1956) was used to test hypotheses. A community dissimilarity matrix (Bray-Curtis) was calculated using species presenceabsence data.

\section{RESULTS AND DISCUSSION}

\section{The Flora}

One hundred and eighty-five vascular plant taxa were recorded from the Reserve, including 21 trees, 13 ferns, 15 grasses, 44 shrubs, 70 herbs, 18 graminoids (Monocotyledonae not in the Poaceae), and four climbers/ scramblers (appendix). Twenty-nine exotic taxa and five Tasmanian endemic species formed part of this rotal. Species from the families Myrtaceae, Proteaceae, Asteraceac, Epacridaceac, Poaceae and Fabaceae dominate the flora. The list of species is incomplete, as collections took place at a time of the year when many taxa were nor evident or identifiable to the species level.

\section{Vegetation}

Of the recognised vascular plant communities in Tasmania (Kirkpatrick et al. 1995), the Coal River Gorge Nature Reserve contains Eucalyptus obliqua-Acacia dealbata-Olearia argophylla wet sclerophyll forest; E. obliqua-O. lirataPultenaea juniperina wet sclerophyll forest; inland Allocasuarina low forest; heathy $E$. amygdalina forest on sandstone; heathy E. tenuiramis forest; shrubby E. obliqua forest; Gonocarpus tetragynus-Stylidium graminifoliumPteridium esculentum heath.

The vegetation map differentiates three dry sclerophyll and two wet sclerophyll communicies (fig. 4). These plant communities are described by their dominant species, faithful species, species richness, the occurrence of exoric and endemic species, vegetation physiognomy and tree basal areas. Their structural and floristic characteristics are summarised in tables 1 and 2 . 


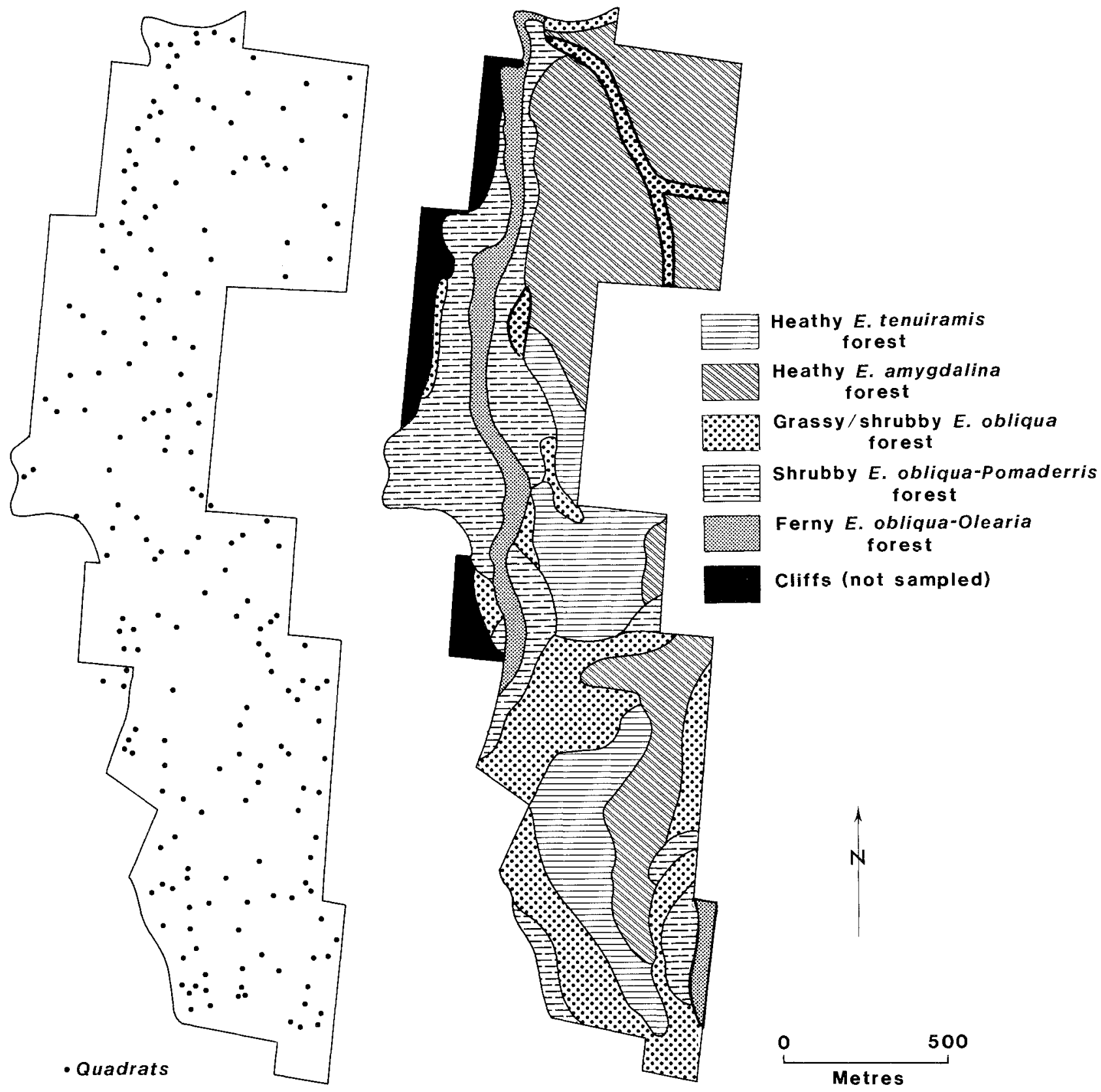

FIG. 4 - Location of sampling sites and plant communities in the Coal River Gorge Nature Reserve.

Group 000 - Heathy Eucalyptus tenuiramis forest

This dry sclerophyll community was found in 46 quadrats on the top of the eastern cliffs. It ranges in altitude from approximately 350 to $410 \mathrm{~m}$. Mean tree height is $23 \mathrm{~m}$ (table 1). The total basal area is $30.37 \mathrm{~m}^{2} / \mathrm{ha}$, and the dominant tree species are E. tenuiramis and E. amygdalina (table 1). The heathy understorey is variably dominated or co-dominated by the shrubs Amperea xiphoclada, Aotus ericoides, Epacris impressa and Tetratheca labillardierei, the herb Stylidium graminifolium and the fern Pteridium esculentum.

Species richness is relatively high $(x=11.50, S D=2.71)$ with only a small proportion of the species $(x=1 \%)$ being exotics. This community contains few endemic species $(\mathrm{x}=1 \%)$, buc these occur in over two-thirds of the quadrats. Species faithful to this group are the shrubs Pimelea linifolia,
Dillwynia sericea and Hibbertia riparia, the herbs Petrorhagia prolifera and Goodenia lanata, and the parasitic climber Cassytha pubescens. The presence of Amperea xiphoclada and/or Aotus ericoides and the absence of Pultenaea juniperina generally discriminate the quadrats in this group from other quadrats. Among recognised communities the group best fits heathy E. tenuiramis forest (Kirkpatrick et al. 1995). However, there are also small areas of Gonocarpus tetragynus-Stylidium graminifolium-Pteridium esculentum heath (Kirkparrick 1977) that floristically belong to this community.

Group 001 - Heathy Eucalyptus amygdalina forest This dry sclerophyll communicy was found in 32 quadrars located on the relatively level sites above the eastern cliff and adjacent to the surrounding farmland. It ranges in altitude 
TABLE 1

Structural and dominance variables for plant communities

\begin{tabular}{|c|c|c|c|c|c|}
\hline & & & Commuı & & \\
\hline & 000 & 001 & 01 & 10 & 11 \\
\hline No. of quadrats & 46 & 28 & 65 & 44 & 17 \\
\hline Classification $^{*}$ & $\mathrm{dsf}_{s}$ & $\mathrm{dsf}$ & $\mathrm{dsf}$ & wsf & wsf \\
\hline Mean \% shrub cover & 40 & 35 & 20 & 10 & $<5$ \\
\hline Mean \% fern cover & $<5$ & $<5$ & $<5$ & 10 & 30 \\
\hline Mean \% grass cover & $<5$ & 20 & 25 & 5 & $<5$ \\
\hline Mean \% leaf litter & 50 & 35 & 30 & 40 & 40 \\
\hline Total tree basal area $\left(\mathrm{m}^{2} / \mathrm{ha}\right)$ & 30 & 27 & 30 & 27 & 22 \\
\hline Eucalyptus tenuiramis basal area & 15 & 5 & 3 & $<1$ & - \\
\hline E. amygdalina basal area & 9 & 12 & 3 & $<1$ & - \\
\hline E. obliqua basal area & 3 & 6 & 13 & 15 & 6 \\
\hline E. virninalis basal area & $<1$ & 1 & 3 & 2 & $<1$ \\
\hline E. globulus basal area & $<1$ & $<1$ & 1.5 & $<1$ & $<1$ \\
\hline Acacia dealbata basal area & - & - & 1 & 1.5 & 2 \\
\hline A. melanoxylon basal area & - & - & $<1$ & 1 & 1.5 \\
\hline Pomaderris apetala basal area & - & - & - & 2 & 5 \\
\hline Olearia argophylla basal area & - & - & - & $<1$ & 4 \\
\hline Dead tree basal area & 3 & 4 & 4.5 & 5 & 5 \\
\hline Mean tree height (m) & 23 & 24 & 23 & 30 & 32 \\
\hline Mean shrub height (m) & 0.5 & 0.4 & 0.7 & 1.1 & 1.4 \\
\hline Mean fern height (m) & 0.8 & 0.7 & 0.8 & 1.2 & 0.6 \\
\hline Mean $\%$ exotics in quadrats & 1 & 4 & 10 & 7 & 1 \\
\hline$\%$ quadrats with exotics & 9 & 36 & 57 & 30 & 6 \\
\hline Mean $\%$ endemics in quadrats & 1 & 8 & 3 & 2 & 1 \\
\hline$\%$ quadrats with endemics & 67 & 68 & 25 & 18 & 6 \\
\hline Mean tree species richness & 2.30 & 2.00 & 1.85 & 2.32 & 2.29 \\
\hline Mean fern species richness & 0.74 & 0.46 & 0.65 & 1.25 & 2.18 \\
\hline Mean shrub species richness & 5.83 & 4.18 & 2.17 & 1.25 & 0.94 \\
\hline Mean grass species richness & 0.50 & 1.82 & 1.97 & 0.82 & 0.12 \\
\hline Mean herb species richness & 1.76 & 2.64 & 3.83 & 2.48 & 0.59 \\
\hline Mean graminoid species richness & 0.33 & 0.79 & 0.69 & 0.20 & 0.00 \\
\hline Mean species richness & 11.50 & 11.89 & 11.15 & 8.32 & 6.12 \\
\hline Standard deviation species richness & 2.71 & 3.27 & 4.40 & 3.35 & 2.06 \\
\hline
\end{tabular}

$* \mathrm{~d} s \mathrm{f}=\mathrm{dry}$ sclerophyll forest, wsf $=$ wet sclerophyll forest .

from approximately 350 to $450 \mathrm{~m}$. Mean tree height is $24 \mathrm{~m}$ (cable 1). The total basal area is $27.85 \mathrm{~m}^{2} /$ ha, not significantly different to that of the heathy E. tenuiramis community. E. amygdalina is the dominant tree species, with E. tenuiramis and E. obliqua also being prominent (cable 1). The heathy understorey is dominated by the shrubs Epacris impressa, Pultenaea juniperina, Tetratheca labillardierei and Acacia dealbata, the herbs Gonocarpus tetragynus and Stylidium graminifolium, and the grass Poa spp.

Species richness is relatively high $(x=11.89, S D=3.27)$ with only a small proportion of species $(x=4 \%)$ being exotic. In comparison to community 000 , the exorics occur in a relatively large proportion of quadrats $(36 \%)$. The mean percentage of endemics in quadrats $(x=8 \%)$ is higher than that found in any of the other communities.

Species faithful to this group are the shrub Acrotriche serrulata, the herbs Gonocarpus humilis, Viola hederacea and Brachyscome aculeata, and the graminoids Schoenus apogon and Diplarrena moraea. The quadrats in this community are generally separated from the other quadrats by the presence of Pultenaer juniperina and the absence of Cassinia aculeata, Aotus ericoides, Amperea xiphoclada, Geranium spp., Oxalis perennans and Senecio linearifolius. This community fits within the heathy E. amygdalina forest on sandstone of Duncan \& Brown (1985).

Group 01 - Grassy/shrubby Eucalyptus obliqua forest This dry sclerophyll community was found in 65 quadrats located mostly on the colluvial slopes around the southern end of the Reserve and within the drainage channel running across the northern end. Small pockets are also located along the cliffs within the gorge. It ranges in altitude from approximately 200 ro $470 \mathrm{~m}$. Tree height averages $23 \mathrm{~m}$ (table 1) E. obliqua is the dominant tree species, and E. viminalis, E. tenuiramis and $E$. amygdalina all occur as subdominants in fairly even proportions (table 1). The total basal area is $28.69 \mathrm{~m}^{2} / \mathrm{ha}$, not significancly different to those of the heathy $E$. tenuiramis and heathy $E$. amygdalina communities. The understorey is dominated by the shrub Cassinia aculeata, the herb Geranium spp., the graminoid Lomandra longifolia and the grass Poa spp. 
Species richness is relatively high $(\mathrm{x}=11.15, \mathrm{SD}=4.40)$ and is very similar to that of the other dry sclerophyll communities $(000$ and 001$)$. This community contains a greater proportion of exotic species $(x=10 \%)$ than any of the other groups and the exoric species are spread throughout a greater proportion of quadrats $(57 \%)$. It contains relatively few endemics.

Species faithful to this group are the shrubs Indigofera australis, Olearia viscosa, Rubus parvifolius and Lissanthe strigosa, the herbs Drosera sp., Geranium spp., Corybas sp., Carpobrotus rossii, Hypericum gramineum, Scleranthus biflorus, Craspedia glauca, Daucus carota, Lagenifera huegelii, Plantago varia and Leptorhynchos squamatus, and the grass Themeda triandra. This community may generally be separated from the others by an occurrence of a combination of species, including at least one from Cassinia aculeata, Geranium spp., Oxalis perennans and Plantago varia, plus at least one from Lomandra longifolia, Wahlenbergia sp., Aira caryophyllea and Exocarpos cupressiformis. These species alone do not sufficiently discriminate this community from the others and, thus, the absences of Amperea xiphoclada, Aotus ericoides, Bossiaea cinerea and Polystichum proliferum are also an important feature

From within community 01 , three subcommunities may be differenciated. One is characterised by Senecio linearifolius and Olearia lirata. A second is characterised by Exocarpos cupressiformis, Plantago varia and Aira caryophyllea. A third is dominated by Allocasuarina verticillata, with an understorey of Lomandra longifolia and grass species. This latter subcommunity is confined to a small pocket on a northwest facing cliff at the southern end. It falls within the inland Allocasuarina low forest of Duncan \& Brown (1985), whereas the remainder of community 01 falls within their shrubby Eucalyptus obliqua forest.

\section{Group 10 - Eucalyptus obliqua-Pomaderris apetala wet} sclerophyll forest

This wet sclerophyll community was found in 44 quadrats. These were located along the colluvial slopes within the gorge. It is situated predominantly below an altitude of $300 \mathrm{~m}$. Mean tree height is $30 \mathrm{~m}$, taller than the previous communities (table 1). The toral tree basal area is $26.71 \mathrm{~m}^{2} /$ ha, slightly lower than that of the communities described previously. There are many standing dead trees (table 1). E. obliqua, Pomaderris apetala and Acacia dealbata are the dominant tree species, with the former constituting the tallest stratum. The understorey is dominated by the herb Senecio linearifolius, the fern Pteridium esculentum and the grass Poa spp.

Species richness is generally lower $(x=8.32, \mathrm{SD}=3.35)$ than that observed within the dry sclerophyll communities, and the proportion of exoric species in quadrats $(x=7 \%)$ is similar to that of communities 000 and 01 . The proportion of endemic species is relatively low $(x=2 \%)$, and they occur in a relatively low proportion of quadrats $(18 \%)$.

Species faithful to this community are the shrubs Acacia verniciflua, Rosa rubiginosa and Olearia phlogopappa, the herbs Lagenifera stipitata, Ranunculus lappaceus, Plantago major and Senecio jacobaea, the climber Clematis aristata and the graminoids Lepidosperma laterale and Juncus pallidus. The quadrats in this group are generally distinguished from other quadrats by the presences either of Pomaderris apetala and/or Polystichum proliferum, or of Pteridium esculentum and/or Poa spp., and an absence of Dicksonia antarctica, Lomandra longifolia, Exocarpos cupressiformis, Aira caryophyllea and Plantago varia. This community falls within the Eucalyptus obliqua-Olearia lirata-Pultenaea juniperina wet sclerophyll forest of Kirkpatrick et al. (1988).

\section{Group 11 - Eucalyptus obliqua-Olearia argophylla wet} sclerophyll forest

This wet sclcrophyll community is located predominantly along the Coal River and occurred in 17 quadrats. It is situated below an altitude of $260 \mathrm{~m}$. The mean tree height is $32 \mathrm{~m}$, the tallest for any community (table 1). The total basal area $(x=22.60, S D=8.04)$ for this community is considerably smaller than those previously observed. There are many standing dead trees (table 1). The dominant tree is E. obliqua. Pomaderris apetala and Olearia argophylla dominate the second stratum. The understorey is dominated by the shrub Coprosma quadrifida and the ferns Dicksonia antarctica and Polystichum proliferum. Dicksonia antarctica is the only species faithful to this group.

This community exhibits the lowest species richness $(\mathrm{x}=6.12, \mathrm{SD}=2.06)$, a low proportion of exoric species $(\mathrm{x}=1 \%)$ and a low proportion of endemics (1\%). This group may gencrally be differentiated from the other communities by the presence of Dicksonia antarctica and/ or at least two species from Coprosma quadrifida, Olearia argophylla, Polystichum proliferum and Pomaderris apetala. Also the absence of Poa spp., Acaena novae-zelandiae, Viola hederacea and Geranium spp. are diagnostic. This community falls within the E. obliqua-Acacia dealbataOlearia argophylla wet sclerophyll forest of Kirkpatrick et al. (1988).

The dry sclerophyll communities from the Reserve are similar in structure and floristics to those described from sandstone elsewhere in the Southern Midlands and Derwent Valley (Hogg \& Kirkpatrick 1974, Duncan \& Brown 1985). The wer sclerophyll forest communities clearly belong to rypes widespread in Tasmania (Kirkparrick et al. 1988).

\section{Community Relationships}

Vascular plant species richness exhibits a trend from high values in the dry sclerophyll communities to relatively low values in the wet sclerophyll communicies (table 1). This trend is also shown in shrub species richness. Fern species richness shows the reverse trend. Tree species richness exhibits little variation, except that it declines slightly in the grassy/shrubby E. obliqua community, and graminoid richness is greatest in the heathy E. amygdalina and grassy/ shrubby Eucalyptus obliqua communities. Grass and herb species richness are greatest in the grassy/shrubby E. obliqua community.

The heathy E. tenuiramis community and the ferny $E$. obliqua-Olearia community are the most dissimilar communities in the Reserve (table 3 ). The hearhy $E$. tenuiramis and the heathy E. amygdalina communities are the most similar communities. The heathy E. amygdalina community and grassy/shrubby E. obliqua community are the next most similar groups. As could be expected, communities occurring in adjacency exhibit a higher degree of floristic similarity with each other than with those more distant, indicating an easily observable continuum of variation related to topographic position. 
TABLE 2

Percentage frequency of species by group*

\begin{tabular}{|c|c|c|c|c|c|}
\hline $\begin{array}{l}\text { TWINSPAN group } \\
\text { Number of quadrats }\end{array}$ & $\begin{array}{c}000 \\
46\end{array}$ & $\begin{array}{c}001 \\
28\end{array}$ & $\begin{array}{l}01 \\
65\end{array}$ & $\begin{array}{l}10 \\
44\end{array}$ & $\begin{array}{l}11 \\
17\end{array}$ \\
\hline Amperea xiphoclada & 93.48 & 21.43 & 1.54 & - & - \\
\hline Epacris impressa & 91.30 & 57.14 & 12.31 & - & - \\
\hline Aotus ericoides & 86.96 & 17.86 & - & - & - \\
\hline Pteridium esculentum & 73.91 & 46.43 & 61.54 & 68.18 & 17.65 \\
\hline Stylidium graminifolium & 67.39 & 57.14 & 35.38 & 4.55 & - \\
\hline Banksia marginata & 54.35 & 21.43 & 6.15 & - & - \\
\hline Eucalyptus tenuiramis & 47.83 & 21.43 & 6.15 & 2.27 & - \\
\hline Bossiaed cinerea & 34.78 & 7.14 & - & - & - \\
\hline Leucopogon collinus & 32.61 & 7.14 & - & - & - \\
\hline Daviesia ulicifolia & 28.26 & 25.00 & 6.15 & - & - \\
\hline Oxylobium ellipticum & 23.91 & 14.29 & 1.54 & - & - \\
\hline Leucopogon ericoides & 21.74 & 10.71 & - & - & - \\
\hline Astroloma pinifolium & 21.74 & 10.71 & - & - & _ \\
\hline Exocarpos cupressiformis & 19.57 & 14.29 & 18.46 & - & - \\
\hline Leptospermum scoparium & 17.39 & 3.57 & 3.08 & _- & _- \\
\hline Leucopogon virgatus & 13.04 & 3.57 & 1.54 & - & - \\
\hline Poa spp. & 36.96 & 85.71 & 80.00 & 54.55 & 5.88 \\
\hline Tetratheca labillardierei & 78.26 & 85.71 & 10.77 & - & - \\
\hline Pultendea juniperina & 8.70 & 71.43 & 20.00 & _- & _ \\
\hline Acacia dealbata & 39.13 & 64.29 & 60.00 & 31.82 & 23.53 \\
\hline Gonocarpus tetragynus & 54.35 & 64.29 & 24.62 & 4.55 & - \\
\hline Eucalyptus a mygdalina & 23.91 & 50.00 & 4.62 & - & - \\
\hline Pterostylis spp. & 28.26 & 50.00 & 16.92 & 2.27 & - \\
\hline Helichrysum scorpioides & - & 32.14 & 7.69 & - & - \\
\hline Dianella tasmanica & 28.26 & 32.14 & 15.38 & - & - \\
\hline Aira caryophyllea & 4.35 & 28.57 & 26.15 & - & _ \\
\hline Lomatia tinctoria & 4.35 & 21.43 & 9.23 & - & - \\
\hline Pimelea humilis & 10.87 & 17.86 & 12.31 & - & - \\
\hline Dichelachne spp. & - & 17.86 & 1.54 & - & - \\
\hline Stipa spp. & - & 14.29 & 10.77 & 2.27 & - \\
\hline Goodenia ovata & 4.35 & 10.71 & 7.69 & - & - \\
\hline Acrotriche serrulata & - & 10.71 & - & - & - \\
\hline Gnaphalium collinum & - & 10.71 & 7.69 & 4.55 & - \\
\hline Cassinia aculeata & 2.17 & 7.14 & 49.23 & 11.36 & - \\
\hline Lomandra longifolia & 4.35 & 39.29 & 46.15 & - & - \\
\hline Geranium spp. & - & - & 36.92 & 20.45 & - \\
\hline Eucalyptus obliqua & 10.87 & 17.86 & 26.15 & 15.91 & - \\
\hline Viola hederacea & - & 3.57 & 23.08 & 22.73 & - \\
\hline Wablenbergia sp. & 6.52 & 3.57 & 21.54 & - & _- \\
\hline Plantago varia & - & - & 21.54 & - & - \\
\hline Oxalis perennans & - & - & 21.54 & 4.55 & - \\
\hline Danthonia spp. & 6.52 & 3.57 & 13.85 & - & - \\
\hline Anthoxanthum odoratum & - & 7.14 & 13.85 & - & - \\
\hline Senecio sp. & - & - & 13.85 & 6.82 & 11.76 \\
\hline Hypochoeris radicata & - & 3.57 & 12.31 & 6.82 & - \\
\hline Senecio lautus & - & - & 12.31 & - & - \\
\hline Olearia lirata & - & - & 23.08 & 59.09 & 23.53 \\
\hline Senecio linearifolius & - & - & 29.23 & 47.73 & 11.76 \\
\hline Acaena novae-zelandiae & - & - & 9.23 & 29.55 & - \\
\hline Hydrocotyle hirta & - & 3.57 & 4.62 & 20.45 & 5.88 \\
\hline Acacia melanoxylon & 6.52 & - & 6.15 & 15.91 & 5.88 \\
\hline Galium australe & - & - & 6.15 & 11.36 & 5.88 \\
\hline Pimelea drupacea & - & - & - & 11.36 & 5.88 \\
\hline Polystichum proliferum & - & - & - & 40.91 & 94.12 \\
\hline Olearia argophylla & - & - & 1.54 & 11.36 & 76.47 \\
\hline Pomaderris apetala & - & - & 7.69 & 65.91 & 70.59 \\
\hline Coprosma quadrifida & - & - & 3.08 & 18.18 & 58.82 \\
\hline Dicksonia antarctica & - & - & - & - & 52.94 \\
\hline Hymenophyllum cupressiforme & - & - & - & 2.27 & 17.65 \\
\hline Phymatosorus pustulatus & - & - & - & 2.27 & 17.65 \\
\hline Stellaria flaccida & - & - & - & 11.36 & 17.65 \\
\hline Australina pusilla & - & - & 1.54 & 4.55 & 11.76 \\
\hline Blechnum wattsii & - & - & - & - & 11.76 \\
\hline Dichondra repens & - & - & 1.54 & 6.82 & 11.76 \\
\hline Pittosporum bicolor & - & - & - & 2.27 & 11.76 \\
\hline
\end{tabular}

- Showing those occurring in more than $10 \%$ of the quadrats in any one group.

$\dagger$ The species are ordered by their abundance within the group within which they are most abundant. 
TABLE 3

Bray-Curtis dissimilarity matrix for plant communities

\begin{tabular}{lccccc}
\hline & 000 & 001 & 01 & 10 & 11 \\
\hline 000 & 0.0000 & 0.3983 & 0.6370 & 0.8073 & 0.9188 \\
001 & 0.3983 & 0.0000 & 0.4878 & 0.7652 & 0.9105 \\
01 & 0.6370 & 0.4878 & 0.0000 & 0.5462 & 0.8203 \\
10 & 0.8073 & 0.7652 & 0.5462 & 0.0000 & 0.5809 \\
11 & 0.9188 & 0.9105 & 0.8203 & 0.5809 & 0.0000 \\
\hline
\end{tabular}

\section{Environmental Relationships}

The surface rock cover is greatest in the wet sclerophyll communities and least in the dry sclerophyll communities. The E. obliqua-Olearia community has a significantly higher rock cover than the E. obliqua-Pomaderris and dry sclerophyll communities, and the shrubby E. obliqua-Pomaderris forest has a higher cover than the dry sclerophyll forests. The grassy/shrubby E. obliqua community has a greater rock cover than the heathy E. tenuiramis and heathy E. amygdalina communities, which exhibit no significant difference between them (table 4).

The slope varies from steep cliffs to relatively level areas on top of the eastern cliff and on the valley floor. The grassy/shrubby E. obliqua and E. obliqua-Pomaderris communities occur on significantly steeper slopes than the other communities, and the heathy E. tenuiramis community occurs on significantly steeper slopes than the heathy $E$. amygdalina community.

The quadrats in the E. obliqua-Olearia wet sclerophyll community occur significantly more on southerly and easterly aspects than on other aspect classes. The quadrats in the E. obliqua-Pomaderris wet sclerophyll forest occur significantly more on southwesterly and northeasterly aspects. The quadrats in the dry sclerophyll communities occur significantly more on westerly and northerly aspects.

The soils in the heathy E. tenuiramis and heathy $E$. amygdalina communities are grey to brown, stony fine sandy loams. Depth ranges from 0.25 to $0.35 \mathrm{~m}$. The soils of the grassy/shrubby E. obliqua and E. obliqua-Pomaderris communities are predominantly brown and are loam to fine sandy loams. Soil depth usually approximates $0.95 \mathrm{~m}$. The soils of the E. obliqua-Olearia community are dark grey to dark brown-black and are fine loamy sands to silty clays with a moderate to low permeability. Soil depth usually approximates $1.4 \mathrm{~m}$.

The heathy E. tenuiramis community is located within a significantly more acidic edaphic environment than any of the other communities, and the heathy $E$. amygdalina community occurs on more acidic soils than the grassy/ shrubby E. obliqua community.

The only significant differences in the percentage weight loss on ignition involved the heathy E. amygdalina community, which had a lower value than both the $E$. obliqua-Pomaderris community and the E. obliqua-Olearia community.

The above data indicate that moisture availability is a major correlate of variation in the vegetation of the reserve. The water-holding capacity of the soils increases from the cliff top to the alluvial flats as a result of both increasing soil depth and a higher proportion of fine particles. Overland flow and ground water would tend to augment the amount of moisture available to be held in the soils of the lower slopes. Also, the magnitude of the impact of insolation on evapotranspiration generally decreases along the vegetation continuum from heathy E. tenuiramis dry sclerophyll forest to E. obliqua-Olearia argophylla wet sclerophyll forest as a result of variation in aspect and the effect of shading from the cliffs.

Tree height has bcen observed to be related to moisture status, with greater moisture availability being reflected in greater height (Kirkpatrick \& Nunez 1980). The vegetation of the Reserve shows a trend in increasing eucalypt and shrub height from the dry sclerophyll communities to the wet sclerophyll communities (table 1), which coincides with the putative increase in soil moisture. The high proportion of dead trees in the wet sclerophyll forests might reflect a failure of downslope flow during the dry summers immediately preceding data collection (cf. Kirkpatrick \& Marks 1985).

TABLE 4

Environmental variables for plant communities

\begin{tabular}{lccccc}
\hline Community & 000 & 001 & 01 & 10 & 11 \\
\hline No. of quadrats & 46 & 28 & 65 & 44 & 17 \\
soil colour & dark grey & dark brown & dark brown & dark brown & black \\
soil depth (m) & $0.25-0.35$ & $0.25-0.35$ & 0.95 & 0.95 & 1.40 \\
Mean pH & 5.0 & 5.7 & 6.0 & 6.2 & 6.0 \\
Standard deviation pH & 0.7 & 0.7 & 0.8 & 1.0 & 1.6 \\
Mean \% weight loss on ignition & 9.6 & 7.8 & 10.3 & 10.8 & 12.4 \\
Standard deviation weight loss & & & & 5.4 & 7.2 \\
on ignition & 5.0 & 4.3 & 15 & 20 & 20 \\
Mean \% bare ground & 30 & $<5$ & 5 & 10 & 20 \\
Mean \% rock cover & $<5$ & $<5$ & 20 & 3 \\
Mean degree ground slope & 5 & 2 & 2 & 3 \\
Aspect* & 2.5 & & & 5 \\
\hline
\end{tabular}

*Aspect coded on ecological similarity as follows: $1=\mathrm{NW}$ (driest aspect); $2=\mathrm{W}, \mathrm{N} ; 3=\mathrm{SW}, \mathrm{NE} ; 4=\mathrm{S}, \mathrm{E} ; 5=\mathrm{SE}$ (wertest aspect). 
Our limited data related to soil nutrient availability, $\mathrm{pH}$ and soil organic content, also indicates an increase from the cliff top to the alluvial flats. However, the magnitude of the differences is much less than with the attributes related to moisture availability. Both $\mathrm{pH}$ and organic content can be as much a function of the vegetation type as a cause of its differentiation. For example, the litter of Pomaderris is know to be rich in calcium, which would increase $\mathrm{pH}$ (Ashton 1976), and soil organic content is a partial function of vegetation productivity (Attiwill \& Leeper 1987). Nevertheless, soils could be expected to be naturally more fertile on the lower slopes, as a result of downslope movement of nutrients through leaching and erosion over time, and because the rocks that tend to form cliff tops are among the more siliceous in a sedimentary series. Certainly, the transition from scleromorphic understoreys to those with substantial components of grasses and broad-leaved shrubs, as recorded in the Coal River Gorge, is typically associated with increasing nutrient status (c.g. Specht 1974).

The codirectionality of moisture and nutrient status makes it impossible to tease out their exact contributions to variation in the vegetation. These gradients may be reinforced by a feedback mechanism between environment, vegetation and litter characteristics and fire frequency, such that fire is least frequent in the valley flats and most frequent on the cliff tops. However, apart from the observation that fire has been more recent on the cliff top than in the valley, we have no data on this subject.

\section{Conservation Significance and Management}

With one exception the species and floristic communities identified in this study are considered to be well reserved (Kirkparrick et al. 1995). The heathy Eucalyptus tenuiramis forest which was once widespread in the southern Midlands and Derwent Valley (Williams 1991) is that exception. The Coal River Gorge Nature Reserve is its sole security.

The nature of the Coal River Gorge poses a number of problems for management. Firstly, it does not occupy a complete catchment. It is situated mostly in a valley and as a result is subjected to runoff from the surrounding pastures on the hill tops. Secondly, it is long and narrow with a correspondingly high perimeter to area ratio. And thirdly, its relatively small size (209 ha) means that it is at risk from a single event, such as fire.

However, the Reserve is contiguous with other relatively undisturbed areas on private property. Much of this land is likely to remain unmodified due to its inappropriateness for agricultural or grazing purposes, but it is realistic to assume that clearance will continue on suitable land. There is a need to encourage the retention of this native bush surrounding the Reserve for a number of reasons. Firstly, it increases the effective size of the Reserve; and, secondly, it acts as a buffer zone between the Reserve and farmed lands.

Exotic species invasion into the Reserve occurs from surrounding private property; and from water-borne seeds carried by the Coal River. Alchough exotic species, such as blackberries, were observed growing adjacent to the river, there is no evidence that they are invading the surrounding wet sclerophyll environment. The majority of exotic species invasion is occurring along the interface between the Reserve and farmland.
We recommend that the presence of willow trees (Salix $a l b a)$ in the Coal River at the southern end of the Reserve be monitored to ensure that they are not being dispersed upstream. The majority of exotic species observed in the Reserve are herbaceous and do nor seem to threaten the native species.

The southern end of the Reserve is subjected to grazing by sheep and cattle from adjacent private property. The cliff line and adequate fencing on most Reserve boundaries appear to prevent grazing from occurring in rhe bulk of the Reserve. We recommend that grazing be totally excluded from the Reserve by the improvement of the boundary fence.

Fire is an integral part of the ecology of the plant communities in the Reserve. The amount of dead wood resulting from extensive tree dieback in both the dry and wet sclerophyll communities may increase the severity of fire if it occurs. Fire sensitive species, such as Olearia argophylla, which gain some protection from fire in the moist gully location, may have their protection decreased by the dead wood which acts as a source of fuel.

The control of fire regimes in dry sclerophyll vegetation is important in management for conservation. For example, fire regimes of less than ten years are known to reduce species richness in most sedgey and heathy dry sclerophyll communities and a regime of less than 20-25 years reduces richness in shrubby communities (Williams 1991). Conversely, richness also declines in these dry sclerophyll communities if the fire-free period is too great.

We recommend that fire be used as a management tool in the dry sclerophyll vegetation if the fire free period becomes great enough to put species richness at risk. Fire should not normally be used as a management tool in the wet sclerophyll vegetation as the need for it is so infrequent and accidental fires are likely to provide for that need.

\section{ACKNOWLEDGEMENTS}

We thank Adrian Pyrke for assistance with computer programmes, Geoffrey Day for assistance with matters concerning computers, and $\mathrm{Mr}$ and Mrs Lyall who provided accommodation near the study area.

\section{REFERENCES}

Ashton, D.H., 1976. Phosphorus in forest ecosystems at Beenak, Victoria. J. Ecol. 64: 171-186.

ATtiWILL, P.M. \& LeFPer, G.W., 1987. FOREST SOILS AND NUTRIENT CYCLES. Melbourne University Press, Melbourne.

Brown, M.J. \& Bayly-Stark, H.J., 1979. The plant communities of the East Risdon Nature Reserve. Tasm. Nat. 71:2-6.

Brown, M. J. \& POoger, F.D., 1982. Floristics and fire regimes of a vegetarion sequence from sedgeland-heath to rainforess at Barhurss Harbour, Tasmania. Aust. J. Bot. 30: 659-676.

BUChanan, A.M., 1995. A CENSUS OF THE VASCULAR PLANTS OF TASMANIA. Tasm. Herb. Occ. Publ. 5.

DUNCAN, F. \& BROWN, M.J., 1985. DRY SCLEROPHYLL VEGETATION IN TASMANIA. Wildl. Div. Tasm. NPWS Tech. Rep. 85/1.

Duncan, F. \& HarrIs, S., 1983. A Botanical study in the Colonels Hills, an area of sclerophyll bushland near Tooms Lake. Tasm. Nat. 10: 5-16. 
ELLis, R.C., 1985. The relationships amongst eucalypt forest, grassland and rainforest in a highland area in northeastern Tasmania. Aust. J. Ecol. 10: 297-314.

HILL, M.O., 1979. TWINSPAN - A FORTRAN PROGRAM FOR ARRANGING MULTIVARIATE DATA IN AN ORDERED TWO-WAY TABLE BY CLASSIFICATION OF THE INDIVIDUALS AND ATTRIBUTES. Ecology and Systematics, Cornell University, New York.

HogG, A. \& KirkPatrick, J.B., 1974. The phytosociology and synecology of some southern Tasmanian eucalypt foresrs and woodlands. J. Biogeogr. 1: 227-245.

JACKSON, W.D., 1968. Fire, air, water and earth - An elemental ecology of Tasmania. Proc. Ecol. Soc. Aust. 3: 9-16.

KiRKPATRICK, J.B., 1977. THE DISAPPEARING HEATH. Tasmanian Conservation Trust, Hobart.

KIRKPATRJCK, J.B., 1991. TASMANIAN NATIVE BUSH: A MANAGEMENT HANDBOOK. Tasmanian Environment Centre, Hobart.

KirKPATRICK, J.B. \& Marks, F., 1985. Observation of drought damage to some native plant species in eucalypt forests and woodlands near Hobart, Tasmania. Pap. Proc. R. Soc. Tas. 119: 15-21

KIRKPATRICK, J. B. \& NUNEZ, M., 1980. Vegetation-radiation relationships in mountainous terrain: eucalypt-dominated vegetation in the Risdon Hills, Tasmania. J. Biogeog. 7: $197-208$

Kirkpatrick, J.B., Peacock, R.J., Cullen, P.J. \& Neyland, M.G., 1988. THE WET EUCALYPT FORESTS OF TASMANIA. Tasmanian Conservation Trust, Hobart.
Kirkpatrick, J.B., Barker, P., Brown, M.J., Harris, S. \& Mackie, R., 1995. THE RESERVATION STATUS OF TASMANIAN VASCULAR PLANT COMMUNITIES. Wildl. Sci. Rep. 95/4. Parks and Wildlife Service, Tasmania,

KMiETOWICZ, Z. W. \& Yannoulis, Y., 1976. MATHEMATICAL, STATISTICAI AND FINANCIAL TABLES FOR THE SOCIAL SCIENCES. Longman Inc., New York.

Mueller-Dombols, M.D. \& Ellenberg, H., 1974. AIMS AND METHODS OF VEGETATION ECOLOGY. Wiley International, New York.

SIEGEL, S., 1956. NON-PARAMETRIC STATISTICS FOR THE BEHAVIOURAL SCIENCES. McGraw-Hill Kogakussha Lid, Japan.

SPECHT, R.L., 1974.THE VEGETATION OF SOUTH AUSTRALIA Government Printer, Adelaide.

WaLTER, E.D., 1974. Determination of carbonate and organic matter in calcarcous sediments and sedimentary rocks by loss on ignition: comparison with other methods. J. Sediment. Petrol. 44: 242-248.

WiLliams, K., 1991. Dry sclerophyll vegetation. In Kirkpatrick, J.B. (Ed.): TASMANIAN NATIVE BUSH: A MANAGEMENT HANDBOOK. Tasmanian Environment Centre, Hobart.

(accepted 20 June 1995) 
APPENDIX

Higher plant species observed in the Coal River Gorge Nature Reserve

\begin{tabular}{|c|c|c|c|}
\hline Trees & P. bumilis & Ranunculus lappaceus & Ferns \\
\hline Acacia dealbata & $P$. linifolia & R. pumilio & Adiantum aethiopicum \\
\hline A. melanoxylon & Pomaderris pilifera & Rorippa dictyosperma & Asplenium flabellifolium \\
\hline Allocasuarina verticillata & Pultenaea juniperina & Scleranthus biflorus & A. terrestre \\
\hline+ Asterotrichion discolor & * Rosa rubiginosa & * Senecio jacobaea & Blechnum nudum \\
\hline Banksia marginata & Tetratheca labillardierei & S. lautus & B. penna-marina \\
\hline Bedfordia salicina & Zieria arborescens & S. linearifolius & B. wattsii \\
\hline Bursaria spinosa & & S. sp. & Dicksonia antarctica \\
\hline +Eucalyptus amygdalina & Climbers/Scramblers & * Sonchus asper & Hymenophyllum cupressiforme \\
\hline E. brookeriana & Cassytha pubescens & ${ }^{*} S$. oleraceus & Pellaea falcata \\
\hline E. globulus & Clematis aristata & * Spergularia rubra & Phymatosorus pustulatus \\
\hline E. obliqua & ${ }^{*}$ Rubus fruticosus & Stackhousia monogyna & Pleurosorus rutifolius \\
\hline E. ovata & R. parvifolius & Stellaria flaccida & Polystichum proliferum \\
\hline+ E. tenuiramis & & ${ }^{*}$ S. graminea & Pteridium esculentum \\
\hline E. viminalis & Herbs & *S. media & \\
\hline Exocarpos cupresijformis & Acaena novae-zelandiae & S. pungens & * introduced species \\
\hline Olearia argophylla & A. ovina & Stylidium graminifolium & + Tasmanian endemic species \\
\hline *Pinus radiata & * Acetosella uulgaris & * Trifolium sp. & \\
\hline Pittosporum bicolor & Ajuga australis & Urtica incisa & \\
\hline Pomaderris apetala & ${ }^{*}$ Anagallis arvensis & * Verbascum thapsus & \\
\hline P. elliptica & Australina pusilla & Veronica calycina & \\
\hline * Salix alba & Brachyscome aculeata & Viola hederacea & \\
\hline & Cardamine sp. & Wahlenbergia quadrifida & \\
\hline Shrubs & Carpobrotus rossii & $W$. sp. & \\
\hline Acacia gunnii & ${ }^{*}$ Centaurium erythraea & & \\
\hline A. verniciflua & * Centranthus ruber & Grasses & \\
\hline Acrotriche serrulata & Chrysocephalum apiculatum & Agrostis spp. & \\
\hline Amperea xiphoclada & C. semipapposum & * Aira caryophyllea & \\
\hline Aotus ericoides & ${ }^{*}$ Cirsium arvense & * Anthoxanthum odoratum & \\
\hline Astroloma humifusum & ${ }^{*}$ C. vulgare & ${ }^{*}$ Cynosurus echinatus & \\
\hline A. pinifolium & ${ }^{*}$ Conium maculatum & Danthonia spp. & \\
\hline Bossiaea cinerea & Craspedia glauca & Deyeuxia quadriseta & \\
\hline Cassinia aculeata & Crassula sieberiana & Dichelachne spp. & \\
\hline Coprosma hirtella & Cynoglossum australe & Ehrharta stipoides & \\
\hline C. quadrifida & Myosotis exarrhena & Elymus scabrus & \\
\hline Cyathodes glauca & * Daucus carota & * Holcus Lanatus & \\
\hline Daviesia latifolia & Dichondra repens & Poa labillardierei & \\
\hline D. ulicifolia & Drosera sp. & P. rodwayi & \\
\hline Dillwynia sericea & Epilobium sp. & $P$ sieberiana & \\
\hline Epacris impressa & Galium australe & Stipa spp. & \\
\hline Goodenia ovata & ${ }^{*}$ Geranium dissectum & Themeda triandra & \\
\hline Ozothamnus ferrugineus & $G$ spp. & & \\
\hline O. obcordatum & Gnaphalium collinum & Graminoids & \\
\hline O. thyrsoideus & Gonocarpus humilis & Bulbine bulbosa & \\
\hline Hibbertia riparia & G. tetragynus & Carex appressa & \\
\hline Indigofera australis & G. teucrioides & C. sp. & \\
\hline+ Leptospermum glaucescens & Goodenia lanata & Chiloglottis reflexa & \\
\hline L. lanigerum & Helichrysum scorpioides & Corybas sp. & \\
\hline L. scoparium & Hydrocotyle hirta & Dianclla revoluta & \\
\hline Leucopogon collinus & Hypericum gramineum & D. tasmanica & \\
\hline L. ericoides & ${ }^{*}$ Hypochoeris radicata & Diplarrena morata & \\
\hline l. virgatus & Lagenifera buegelii & Isolep is cernua & \\
\hline Lissanthe strigosa & L. stipitata & Juncus pallidus & \\
\hline+ Lomatia tinctoria & * Leontodon taraxacoides & J. pauciflorus & \\
\hline Olearia lirata & Leptorbynchos squamatus & Lepidosperma laterale & \\
\hline O. phlogopappa & Oxalis perennans & Lomandra longifolia & \\
\hline O. ramulosa & Pelargonium australe & Luzula sp. & \\
\hline O. viscos $a$ & * Petrorhagia prolifera & Pterostylis spp. & \\
\hline Oxylobium ellipticum & * Plantago major & Schoenus apogon & \\
\hline Persoonia juniperina & $P$ varia & Tetraria capillaris & \\
\hline Pimelea drupacea & Poranthera microphylla & Triglochin procera & \\
\hline
\end{tabular}

